\title{
LAUDATO SI': SOBRE O CUIDADO DA CASA COMUM - um guia de leitura -
}

\section{LAUDATO SI': on CARE FOR OUR COMMON HOME} - a reader's guide -

\author{
Gilmar Zampieri*
}

\section{RESUMO}

Este artigo constitui um guia de leitura, da encíclica do Papa Francisco, aqui definido como um líder moral e intelectual com coragem de profeta. Oferece um mapa para orientar o leitor da encíclica e para possibilitar, aos que não puderem lê-la, uma compreensão mínima de seus pontos principais e de seus argumentos. Seguindo os passos do próprio texto, frisa o que parece ser o mais relevante em cada parte. No final, o Autor ensaia uma interpretação pessoal do documento.

Palavras-chave: Encíclica. Casa comum. conversão ecológica e integral. Espiritualidade ecológica.

\section{ABSTRACT}

This article presents some guidelines for reading Pope Francis' encyclical letter, who is regarded here as a moral as well as intellectual leader, one that possesses the courage of a prophet. Furthermore, it offers both a map to orientate the reader and an overview of its central concerns and arguments to those who may not be able to read it. The paper follows the steps of the text itself and highlights what appears to be most important in each chapter. At the end, the author attempts a personal interpretation of the document.

Keywords: Encyclical letter. Common home. Ecological and integral conversion. Ecological Spirituality.

* Mestre em filosofia e em teologia pela PUCRS. Professor na ESTEF e na UNILASALLE.

\begin{tabular}{|l|l|l|l|l|l|}
\hline Teocomunicação & Porto Alegre & v. 46 & n. 1 & p. 4-23 & jan.-jun. 2016 \\
\hline
\end{tabular}


Há homens e mulheres cuja liderança está à altura dos desafios e do espírito do tempo. Lá onde há o perigo, cresce também a salvação (Heidegger). É essa dupla sensação que nos assalta ao ler a encíclica do Papa Francisco, Laudato si', Sobre o Cuidado da Casa Comum.

Um líder moral e intelectual com coragem de um profeta. Este é o Papa Francisco. A casa é comum, o perigo e o destino também. Por isso a encíclica é endereçada a todos os "habitantes do planeta" e não somente aos fiéis católicos. Como reiteradamente L. Boff tem dito: Desta vez não há uma arca de Noé que salve a alguns e deixe perecer os outros. Ou nos salvamos todos ou pereceremos todos.

A encíclica é apresentada em seis capítulos, precedidos de uma introdução e, no final, duas belíssimas orações, intituladas: Oração pela nossa terra e Oração cristã com a criação.

Laudato si' tem quase 200 páginas, com 246 parágrafos, escritos sob o método ver, julgar e agir. Ler cada um dos parágrafos é uma aventura a uma conversão ecológica que só a fé e a boa vontade podem operar.

A encíclica é um verdadeiro exemplo de como a religião e a teologia devem prestar atenção aos sinais dos tempos e lê-los a partir da Escritura e da Tradição. Assim como se deve ler a Escritura a partir dos sinais dos tempos.

Pretendo oferecer neste artigo uma espécie de mapa para orientar futuros leitores da encíclica ou, para os que aqueles que não puderem lê-la, tenham uma compreensão mínima dos seus principais pontos e argumentos.

Para efeito didático sigo os passos do próprio texto, respeitando sua estrutura interna, trazendo à luz o que parece ser o mais relevante, sem pretender fazer uma hermenêutica do próprio texto. No final, em forma de conclusão, arriscarei ensaiar algum lance de interpretação.

O texto principia com uma apresentação em que aparecem, além do tema e do problema, os inspiradores principais da encíclica e a postura dialogante e esperançosa que perpassa o texto do início ao fim. Na minha percepção três pontos merecem destaque na introdução:

a) Primeiramente a evocação de São Francisco de Assis. São Francisco é o inspirador por excelência da encíclica Laudato Si, cujo título o Papa toma emprestado de $O$ cântico das criaturas. São Francisco, nos diz o Papa Francisco, "manifestou uma atenção particular pela criação de Deus e pelos mais pobres e abandonados" (n. 10), sendo o "exemplo por excelência do 
cuidado pelo que é frágil e por uma ecologia integral, vivida com alegria e autenticidade" (n. 10).

b) Em segundo lugar o Papa Francisco faz uma bela menção ao Patriarca Bartolomeu lembrando uma passagem profética deste em que dizia que não se peca somente contra o outro e contra Deus, mas todo mal que fazemos a qualquer ser da criação é "crime contra nós mesmos e um pecado contra Deus" (n. 8). Agredir a natureza é um pecado!

c) Por fim, uma palavra de esperança, apesar da preocupação pelo estado atual de agressão à natureza. Mesmo no perigo e ameaça à casa comum, o Papa nos consola dizendo que "o Criador não nos abandona, nunca recua no seu projeto de amor, nem se arrepende de nos ter criado". E arremata: "a humanidade possui ainda a capacidade de colaborar na construção da nossa casa comum" (n. 13).

Papa Francisco mostra-se homem guiado pelo Espírito Santo de Deus que, na esteira de João Paulo II e Bento XVI, transforma, através dessa encíclica, o tema da Ecologia integral, não apenas oferecendo fragmentos de reflexão, mas fazendo dele um tema sistemático da Doutrina Social da Igreja.

\section{O que está acontecendo com a nossa casa comum?}

O primeiro capítulo da encíclica é uma tentativa de localizar a crise ecológica fazendo um diagnóstico dos sintomas principais. O título do capítulo é $O$ que está acontecendo com a nossa casa comum, indicando claramente de se tratar do ver no já consagrado método pastoral e teológico ver, julgar e agir.

O que está acontecendo de tão grave que mereça a "dolorosa consciência" de todos? Essa pergunta orienta a primeira parte da encíclica e o Papa nos recorda: a) poluição causada pela indústria, pela queima de combustíveis, pelos agrotóxicos, pelos resíduos não biodegradáveis que tornam a terra, nossa casa comum, um "depósito de lixo". Problemas ligados à "cultura do descarte", que precisam ser enfrentados por um modelo circular de produção em que se modere o consumo, se recicle e se reutilize; b) aquecimento sistêmico global, por efeitos naturais e por ação direta da atividade humana que libera gases de efeito de estufa (anidrido carbônico, metano, óxido de azoto e outros) pondo em perigo a vida na terra de boa parte da população mundial, 
sobretudo os pobres; c) as águas, sua qualidade e sua escassez, afetando principalmente os pobres, ferindo-lhe a "dignidade inalienável"; d) perda da biodiversidade que poderia nos ser útil, recurso para a produção e para pesquisa em favor do humano, mas, sobretudo, sentencia o Papa, a perda da diversidade de espécie tem que ser avaliada pelo valor em si dessas espécies e não somente para nós. Por nossa ação predatória, diz profeticamente o Papa, "milhares de espécies já não darão glória a Deus, com sua existência" (n.33), sugerindo uma ecologia do profundo que ultrapassa o utilitarismo imediato como critério do bom; e) deterioração da qualidade da vida humana e degradação humana, sobretudo dos mais vulneráveis; f) desigualdade planetária em que os mais afetados pelas agressões ambientais são as pessoas mais pobres que clamam por justiça.

Os problemas estão conectados e, como é próprio do método do Papa Francisco (já presente no Evangellium Gaudium), é preciso ter uma compreensão holística, do todo, pois as partes só podem ser pensadas no todo. Do ponto de vista da reflexão ecológica o Papa aplica o mesmo método, apontando assim para uma ecologia integral.

Na parte final da análise da realidade, o Papa faz uma constatação preocupante. A reação da política internacional aos problemas apresentados tem sido insuficiente e demasiadamente tímida, causando preocupação real. Fica a impressão de que interesses particulares de âmbito econômico se sobrepõem ao interesse comum que só a política poderia estabelecer, mas já não estabelece porque a política tornou-se refém da economia e da lógica do "paradigma tecnoeconômico" (n.53) e do "mercado divinizado" (n. 56). Esse paradigma e lógica de mercado, escamoteia ou disfarça a realidade fazendo de conta que nada está acontecendo de profundo, tentando paliativamente resolver, na superfície, casos isolados, para que nada mude na vida, na produção e no consumo (n. 59).

Qual seria a solução? O Papa aqui é cauteloso. Como bom dialético apresenta duas teses opostas e aponta para a síntese. Uma tese diz que tudo é uma questão de ajuste técnico e o progresso se estabelecerá infinitamente sem necessidade de freio ético. A tese oposta diz que o homem é irremediável e que a única solução é impedir qualquer ação agressiva contra a natureza. Entre as duas posições, o Papa aponta para uma terceira aberta, dizendo que em casos complexos "não existe só um caminho de solução" (n. 60). Não cabe à Igreja, diz o Papa, apontar as soluções definitivas, mas cabe a ela, como a outros agentes sociais, 
propor o debate, respeitando as opiniões diversas, para soluções mais viáveis e duradouras. O Papa não é pessimista. Nesse aspecto finaliza dizendo: "A esperança convida-nos a reconhecer que sempre há uma saída, sempre podemos mudar de rumos, sempre podemos fazer alguma coisa para resolver os problemas" (n. 61).

\section{O evangelho da criação}

O segundo e terceiro capítulos da encíclica do Papa Francisco, intitulados $O$ Evangelho da Criação e $A$ raiz humana da crise ecológica, é o que constituem o momento do julgar, no método ver, julgar e agir. O momento julgar é o momento de lançar luzes para compreender a realidade no horizonte das Escrituras e à luz da ciência. Assim, mesmo que a Encíclica seja dirigida a todos, e não só aos católicos, o Papa não se exime de falar também e, sobretudo, a partir do Evangelho, certo de que "ciência e religião, que fornecem diferentes abordagens da realidade, podem entrar num diálogo intenso e frutuoso para ambas" (n. 62).

Então, o julgar se divide em duas partes. Uma propriamente teológica e outra colhendo o que há de mais consensual nas ciências no que se refere às causas da crise ecológica.

No que se refere ao julgar teológico, o Papa parte de duas perguntas orientativas: a) Que luz a fé oferece para que se cuide da natureza e dos mais vulneráveis? b) Quais os compromissos ecológicos que brotam das nossas convicções de fé?

No meu entendimento, seis pontos merecem aqui destaque, como resposta a essas perguntas orientativas:

a) Somos feitos a imagem de Deus e com dignidade, somos alguém e não algo. Mas somos alguém ao lado de Deus e da Natureza, em estreita relação de interconexão. As narrativas bíblicas da criação apontam para a harmonia dessa tríplice relação, mas o pecado rompe essa harmonia e o homem se torna agressivo, violento e injusto. Explora a natureza, rompe com Deus negando-o e nega o outro, matando-o (n. 66 e 70);

b) Não somos Deus e é equivocada e errada a interpretação, algumas vezes feita até mesmo pela tradição eclesial cristã, de que, em sendo a parte consciente da criação, podemos dispor do resto da natureza como bem entendermos. O mandato de dominar a criação não dever ser lido sem uma justa 
hermenêutica. E a justa hermenêutica só pode ser do "cultivar e guardar" e não de destruir e subjugar (n. 67);

c) Chamados à responsabilidade. Há uma responsabilidade por parte do humano em preservar o que é de Deus, a terra e tudo o que há nela, sobretudo os animais, pois a culminância da criação não é o homem, mas o sábado da confraternização. Em relação aos animais, o Papa tem uma postura que não deixa nada a dever aos mais representativos defensores dos direitos dos animais. Diz o Papa: "somos chamados a reconhecer que outros seres vivos têm um valor próprio diante de Deus [...] pelo simples fato de existirem, eles O bendizem e Lhe dão Glória". Ora, dizer que os animais têm "um valor em si mesmos" (n. 69) é questionar de uma forma radical o antropocentrismo que, aos moldes Kantianos, só vê valor em si no humano e tudo o mais teria apenas valor instrumental;

d) Pela Criação, obra de amor e não do acaso, cada coisa, mesmo a mais insignificante, recebe um selo de dignidade pelo bem querer de Deus a cada um dos seres criados. Criação significa ato livre de Deus que opera, não por necessidade, mas por liberdade e amor. Essa postura repropõe uma ecologia do profundo em que tudo o que é merece ser respeitado pelo que é. A terra, as montanhas, as águas, o sol, a lua, e não só os seres vivos, são, no dizer do Papa, "carícias de Deus" e manifestações do divino. Nenhuma das criaturas se basta e todas se relacionam e apontam para além delas, para Deus. O ser humano, claro, é a parte consciente da criação, e nele "a capacidade de reflexão, o raciocínio, a criatividade, a interpretação, a elaboração artística e outras capacidades originais" (n. 81) o lançam para além do físico e biológico, transcendendo qualquer determinação da matéria, o que o faz com uma qualidade particular de pessoalidade não passível de ser reduzido à coisa e a algo. Isso, contudo, não o faz senhor do mundo, com poderes despóticos, pois "o fim último das restantes criaturas não somos nós", o fim último é Deus, cuja antecipação já a temos em Cristo ressuscitado e glorificado, imagem do Deus invisível do qual também somos imagem.

e) A comunhão universal ou a "união íntima com os outros seres da natureza" deveria nos fazer sentir como mutilação em nós, as mutilações que provocamos a qualquer dos seres. Além 
do que, causar mal aos animais nos predispõe causar mal aos humanos. E causar mal aos humanos nos predispõe a causar mal aos animais. Tudo está interligado e como o coração é um só, "a miséria que leva a maltratar um animal não tarda e manifestar-se na relação com as outras pessoas" (n. 92).

f) Por fim, uma palavra sobre Jesus. Jesus está longe de se desinteressar por este mundo, pelo corpo, pelo trabalho; e a sua vida, morte e, sobretudo, ressurreição glorificam toda a criação; e esta já não aparece como uma realidade meramente natural, mas recebe em Jesus ressuscitado uma marca indelével de sobrenaturalidade e plenitude.

\section{A raiz humana da crise ecológica}

No terceiro capítulo da encíclica, ainda dentro do julgar, o Papa traça uma análise crítica da Raiz humana da crise ecológica. $A$ análise crítica se impõe para não somente ficar nos sintomas, mas avançar até as causas mais profundas (n. 15) da crise ecológica. E as causas, diz o Papa, límpido e claro, são de dupla natureza, mesmo que conectadas: o paradigma tecnocrático dominante (sistema capitalismo) e o antropocentrismo.

a) Paradigma tecnocrático. A tecnologia não é um mal em si. Pelo contrário, ela é fruto da criatividade e inventividade humana a serviço de nosso bem estar, e não há como não louvar, diz o Papa, o progresso no campo da medicina, comunicações e engenharias etc, que alcançamos nos últimos 200 anos de história. Quando bem orientada, a tecnologia pode produzir coisas maravilhosas a serviço de todos. Mas não dá para ignorar o perigo que ela representa quando concentrada em algumas mãos apenas. E o perigo cresce porque "o imenso crescimento tecnológico não foi acompanhado por um desenvolvimento do ser humano quanto à responsabilidade, aos valores, à consciência" (n. 105). O ser humano é um perigo para si mesmo quando se pretende totalmente autônomo e sem "uma ética sólida, uma cultura e uma espiritualidade que lhe ponham realmente um limite e o contenham dentro de um lúcido domínio de si” (n. 105). A questão é que a tecnologia parece não se importar com valores e ela mesma assume o caráter de fim, dominando tanto a economia quanto a política 
(n. 109), deixando rastros de destruição do meio ambiente e exclusões sociais em nome do lucro, da "maximização dos ganhos" e do "crescimento infinito ou ilimitado" (n. 106). E se engana quem supõe que a tecnologia seja neutra e possa ser usada somente como meio. Ela impõe um estilo de vida em que o sujeito torna-se objeto, ficando refém do que ele mesmo criou. A técnica passa a ser, quando sem limites éticos e sem controle consciente, fim em si mesmo que exige sacrifícios no altar da modernização globalizada, sob o império do ser dominado pelo consumo e pela inovação sem fim. O Papa, porém, não é pessimista. Ainda acredita ser capaz de reorientar a técnica, colocando-a a serviço não de um modelo de progresso que degrade a natureza, mas a um "tipo de progresso, mais saudável, mais humano, mais social, mais integral" (n. 112).

b) O paradigma antropocêntrico. O paradigma tecnológico é, na verdade, um subproduto do antropocentrismo. Uma equivocada interpretação da posição do homem no cosmos, achando-se o centro e senhor da criação, submetendo tudo o mais a seu favor, é a responsável maior pela nossa ação agressiva irresponsável da natureza. É preciso reconhecer, diz o Papa, que "tudo está conectado" e que não há superior e inferior, dominador e dominado, mas uma comunidade de vida que ao homem cabe bem administrar. Nesse aspecto o Papa propõe uma antropologia que seja capaz de superar o "antropocentrismo desordenado" (n. 118) e, em seu lugar, abrir espaço, não para um biocentrismo (n. 118) que também não seria correto, mas para um antropocentrismo ordenado no sentido que o homem seja um "administrador responsável" (n. 116), que supere uma cultura do descarte e do relativismo que "provoca ao mesmo tempo a degradação ambiental e a degradação social" (n. 122). É preciso, diz o Papa, superar o antropocentrismo desordenado que gera um estilo de vida que conduz a um "relativismo prático" que coloca no centro absoluto os interesses individuais e tudo o mais se torna relativo. O relativismo prático é nefasto e faz escravos humanos e animais, obrigando a trabalhos forçados, a tráfico de humanos, de órgãos ou de drogas sem limite, em que o valor único é o "usa e joga fora". Sem valores que imponham limites ao próprio humano e que valham universalmente, não há como ultrapassar o antropocentrismo desordenado. 
Por fim, uma palavra sobre o trabalho e a inovação biológica. Cabe ao humano, numa antropologia responsável, tanto cuidar da natureza quanto cultivá-la para que produza frutos (n. 124). O trabalho quando bem orientado responde à vocação humana que é de ser co-criador em favor da vida. A técnica não pode substituir o trabalho, sob pena de o homem perder o "sentido da vida". Quanto à inovação biológica e manipulação genética, vegetal ou animal, não representam um mal em si, desde que orientados dentro "limites éticos" que não tragam consequências que sejam descontroladas e prejudiciais à saúde e ao meio ambiente.

\section{Uma Ecologia integral}

O quarto capítulo pode ser considerado o coração da encíclica, pois é nele que transparece o que o Papa entende ser a solução no trato da questão ecológica, pelo menos teoricamente. Trata-se de pensar de forma integral, porque, como em várias ocasiões o texto lembra, "tudo está conectado". E se tudo está conectado, então será fundamental pensar na forma integrada como os seres vivos se relacionam entre si e com o meio ambiente. É exatamente isso que o Papa entende por ecologia integral. E o faz destacando várias possíveis dimensões do todo, a saber:

a) Ecologia ambiental, economia social. Tudo está relacionado entre si, do subatômico aos vários elementos físicos, químicos e biológicos do planeta. Ora, a ecologia é exatamente o estudo de como se dá a relação entre os seres vivos e o meio ambiente. Então, falar de meio ambiente é falar dos seres vivos e falar dos seres vivos é falar do ambiente em que vivem. Um ambiente degradado significará, para efeito interpretativo de uma ecologia integral, um ser vivo que se comporta desajustadamente. Nesse aspecto é preciso conectar meio ambiente e sociedade, pois "não há duas crises separadas, uma ambiental e outra social; mas uma e complexa crise socioambiental".

b) Ecologia cultural. Não só o meio ambiente encontra-se ameaçado. A ecologia integral envolve também o "cuidado das riquezas culturais da humanidade". Cultura entendida não como a soma dos monumentos do passado, mas especialmente no seu sentido vivo, dinâmico e participativo. O sistema consumista globalizado tende a desprezar as culturas locais que fazem a riqueza da diversidade cultural mundial. Os símbolos e hábitos das culturas locais devem, portanto, ser preservados 
e estimulados. Nesse aspecto, cultura e meio ambiente se reclamam reciprocamente. Destruir o meio ambiente leva consigo a destruição de identidades culturais singulares. " $\mathrm{O}$ desaparecimento de uma cultura pode ser tanto ou mais grave do que o desaparecimento de uma espécie animal ou vegetal" (n. 145). E a imposição de um modo ou estilo de vida, como é o dominante consumista, pode ser mais nocivo do que a destruição de um ecossistema. Neste sentido as culturas originárias devem ser preservadas e com elas as suas terras que são um espaço sagrado e não só uma fonte econômica a ser explorada. O Papa insiste aqui para que se repensem os grandes projetos extrativos e agropecuários que não prestam atenção para a destruição das culturas.

c) Ecologia da vida cotidiana. O ambiente em que vivemos diz da nossa identidade e influencia no nosso modo de ver a vida, sentir e agir. Ambiente degradado, vida infeliz. Louvável, diz o Papa, são as iniciativas de melhoria do meio ambiente, mesmo em situações precárias de habitação em meio à pobreza. "É louvável a ecologia humana que os pobres conseguem desenvolver, no meio de tantas limitações" (n. 148). Ás vezes, limitações ambientais, de infra-estrutura, sobretudo em bairros pobres, são compensadas pelo calor humano, hospitalidade, acolhida que fazem com que as pessoas se sintam "numa rede de comunhão e de pertença" (n. 148). Assim como, também, é bem provável que num ambiente degradado, acrescido à falta de relações de humanização, favoreça o surgimento de todo tipo de violência e degradação. Para quem pensa o espaço urbano, tem que ter em mente que não basta a arquitetura ser bela, tem que criar e preservar espaços que favoreçam a convivência e a qualidade de vida, despertando assim o sentimento de "estar em casa". O Papa insiste ainda na importância da "casa própria", da "urbanização dos bairros", "do transporte público" de qualidade, na vida caótica de algumas cidades e nas situações de quase escravidão a que são submetidos os trabalhadores nas zonas rurais. E, finalmente, a ecologia humana requer aceitação, cuidado e respeito com o próprio corpo.

d) Oprincípio do bem comum: A ecologia humana se conecta com a noção de bem comum. O bem comum é um princípio político e de ética social indispensável para pensar a vida em comum na 
casa comum. E quando se fala em bem comum estamos falando de respeito pela pessoa humana, por seus direitos inalienáveis, estamos falando de bem estar, segurança social, de paz e justiça para conter as violências de todo tipo que depõe contra o bem comum. Ao Estado cabe a defesa desses direitos. E hoje, com as desigualdades em processo de exacerbação, cabe reafirmar, diz o Papa, a necessária "opção preferencial pelos pobres" para que o discurso do bem comum tenha eficácia e não fique somente no discurso.

e) A justiça intergeracional. A noção de bem comum engloba também as gerações futuras. Não é mais possível falar de desenvolvimento sustentável sem incluir as gerações futuras na mesa da conversa. E aqui o Papa é mais uma vez profético e crítico sutil ao capitalismo, mesmo sem dizer o nome. Ele diz que a terra é uma herança comum, é de todos, inclusive das gerações futuras. Não podemos admitir que a terra seja propriedade de alguns em vista do seu bem individual. $\mathrm{O}$ critério da relação com a terra não pode ser utilitarista e em vista da produtividade. Ela é, antes de qualquer coisa, graça de Deus que precisa ser cuidada para que as futuras gerações possam receber essa herança da melhor forma possível. "A terra pertence também àqueles que hão de vir" (n. 158). Uma ecologia que se queira integral não pode desconsiderar, portanto, a pergunta: que mundo queremos deixar para as crianças que estão crescendo e aquelas que ainda nem nasceram? E mundo aqui significa tanto o meio ambiente quanto o mundo de sentido e valores. Nesse sentido o apelo é para que se supere o mundo do relativismo subjetivista e individualista que transforma tudo e a todos em meio para o fim econômico de produção e consumo que causam desequilíbrios ecológicos sem precedentes. Ainda há tempo, mas é preciso perguntar-se pelo sentido de nossas vidas para além do dominador e consumidor. Para tanto, será preciso um esforço gigantesco de conversão ética, mudando o modo de ser autocentrado, para um modo de ser aberto e solidário.

\section{Linhas de ação}

Os dois últimos capítulos (V e VI) da Encíclica são dedicados exclusivamente a traçar um caminho de diálogo e de ações que apontem 
para a saída da espiral de autodestruição a que submetemos à casa comum. O Papa tem consciência de que não basta analisar o sintoma, fazer o diagnóstico, é preciso apontar para a ação. E como ninguém, muito menos a igreja, deve pretender ter o monopólio da solução, então, a atitude prática elementar é buscar o diálogo. A Igreja entra nesse diálogo provocando um debate honesto e transparente para que a ideologia não cegue o foco maior que é o do bem comum.

Cinco são, segundo o Papa, os níveis do diálogo em vista da superação do atual estado das coisas:

a) O diálogo sobre o meio ambiente na política internacional. $\mathrm{O}$ atual estágio de interdependência global exige que se pense e se aja globalmente para, por exemplo, "programar uma agricultura sustentável e diversificada, desenvolver formas de energias renováveis, promover uma gestão mais adequada dos recursos florestais e marinhos, garantir a todos o acesso à água potável" (n. 164). Não dá para imaginar que isso se possa fazer isoladamente. A transição energética das fontes atuais (carvão, petróleo e gás) para fontes de menor impacto ambiental precisa ser encaminhada urgentemente, porém, "a política e a indústria reagem com lentidão, longe de estar à altura dos desafios mundiais" (n.165). O esforço do movimento ecológico mundial tem sido significativo no avanço da consciência da necessidade de buscar saídas ao problema ecológico. Mas as cúpulas mundiais, apesar de vários encontros, ainda não saíram do âmbito do discurso para o âmbito da ação. Ainda é tênue o cuidado com a biodiversidade e com o controle no avanço da desertificação. Assim como no controle das emissões dos gases de efeito estufa que potencializam o aquecimento global. O atual estágio das ações internacionais além de tímidas ainda são parte de uma estratégia de controle das nações mais ricas impondo uma carga a mais aos países pobres que sofrem na lógica do capital, sobretudo especulativo, inclusive em relação ao meio ambiente, através da compra e venda de "crédito de carbono". Porém, não pode haver ilusões. Será preciso apostar cada vez mais em alguma autoridade política mundial para fazermos frente aos problemas que também são globais.

b) O diálogo para novas politicas nacionais e locais. As questões referentes ao meio ambiente não são só um problema de 
organismos internacionais. No interior das nações também há muito a se fazer. Pelo direito, aparato jurídico, os Estados podem e devem intervir no que diz respeito ao cuidado com o meio ambiente. Nesse aspecto é preciso pensar a longo prazo e não só no imediato da vida política. Às vezes será preciso não ser populista e fazer o que tenha de ser feito, independente dos aplausos da maioria. Para isso, tem-se que ter coragem e um projeto de nação, mais do que agenda política para ganhar eleições. Os estados nacionais e a sociedade civil podem fazer muitas coisas, por exemplo: promover formas de poupança energética, boa gestão de transporte, técnicas de construção de edifícios que reduzam o consumo energético, educar para redução de consumo, reciclagem do lixo, proteção de espécies, agricultura diversificada, infraestrutura rural melhorada, organização de mercados locais, sistemas de irrigação, fomentar formas de cooperação, defender os pequenos produtores, salvaguardar ecossistemas locais...

c) Diálogo e transparência nos processos decisórios. A corrupção é um aliado da degradação ambiental. Projetos claros e transparentes, com controle social, são sempre favoráveis ao meio ambiente. Qualquer projeto de impacto ambiental deveria passar por estudos interdisciplinares e independentes das pressões políticas e econômicas. A avaliação prévia, com participação da comunidade local, dos custos e benefícios de um empreendimento não pode só trabalhar com os dados econômicos, mas sobretudo o ambiental, para que a ética possa ser o horizonte da economia e da política.

d) Política e economia em diálogo para a plenitude humana. $\mathrm{O}$ bem comum e a qualidade de vida são o parâmetro para se avaliar a política e a economia, diz o Papa. Bens ambientais são aqueles em que o mercado não é naturalmente um bom cuidador e protetor. É mais fácil o mercado especular, e os bancos são os mais cruéis nisso, ao invés de realmente proteger o que é de todos. O capital especulativo tem sido desastroso para a humanidade, crise após crise, o que temos é mais desregulamentação e mais facilidade de ação impune. É preciso um freio no conceito de progresso infinito e na especulação onde dinheiro gera dinheiro sobre a morte dos mais fracos. É preciso dar um basta à ideia de que é possível 
crescer infinitamente de forma sustentável. Isso é falácia que não se sustenta.

e) As religiões no diálogo com as ciências. Neste ponto o Papa apela para a humildade da ciência e sua metodologia em reconhecer que nem tudo ela é capaz de dar conta. A fé, a religião e a ética religiosa, mesmo sabendo que há éticas laicas, estão abertas e em diálogo com a razão e as ciências, e estas precisam acolher o que as religiões têm como manancial de sabedoria para a solução dos graves problemas atuais. Mas os próprios crentes têm que se submeter a uma conversão ecológica reconhecendo que, na tradição, fomos levados a justificar guerras, injustiças, domínio despótico do ser humano sobre a criação, sendo assim infiéis "ao tesouro de sabedoria que devíamos guardar" (n.200). A maior parte dos habitantes da terra se declara crente e isso deveria levar as religiões a entrar em diálogo para salvar o que é comum: "cuidado com a natureza, a defesa dos pobres, a construção de uma rede de respeito e fraternidade" (n.201). De outro lado, é fundamental um diálogo entre as próprias ciências, pois, as especializações tendem ao isolamento e à fragmentação. Torna-se também necessário um amplo diálogo entre os movimentos ecológicos para que o bem comum seja o grande horizonte e não cada um ficar defendendo o seu interesse próprio.

\section{Educação e espiritualidade ecológicas}

Como podemos esperar mudanças de comportamento se não mudar o sujeito da ação? É o humano que precisa mudar e, para isso, o Papa aposta na educação e na espiritualidade ecológicas para uma verdadeira conversão. E para uma verdadeira mudança do humano o Papa aponta alguns caminhos:

a) Outro estilo de vida. É preciso evitar o consumismo obsessivo, fruto do vazio que o mercado ou o paradigma tecnoeconômico impõe a todos; consumismo que busca preencher o vazio através de produtos que, por serem descartáveis, exigirá uma lógica de comprar, possuir e consumir. A obsessão pelo consumo gera violência porque nem todos podem, de fato, entrar na lógica do mercado. Quem fica de fora se frustra, vive infeliz e apela para a violência. Essa imposição do mercado é 
contra a dignidade humana que só é digna se puder dizer não, se mantiver o valor da autodeterminação livre para escolher "o bem" e não "os bens". Impõe-se então um novo estilo de vida, com consumo consciente e com capacidade de dizer não a produtos e empresas que degradam a natureza.

b) Educar para o cuidado criando novos hábitos. É preciso ter capacidade de renúncia às ofertas do mercado. Há um desafio educativo em negar a forma de felicidade que o mercado exige dos indivíduos. E para uma boa educação ambiental não basta não causar danos à natureza de forma direta, mas é preciso se conscientizar dos "mitos da modernidade baseados na razão instrumental" (n. 210): individualismo, progresso ilimitado, concorrência, consumismo, mercado sem regras. Além disso, para uma boa educação é preciso recuperar os distintos níveis do equilíbrio ecológico: o interior consigo mesmo, o solidário com todos os seres vivos, e o espiritual com Deus. Para isso, é necessário mudança nos comportamentos que degradam a natureza: evitar o uso do plástico e papel, reduzir o consumo de água, separar o lixo, não desperdiçar comida, usar transporte público, plantar árvores, apagar as luzes desnecessárias, etc. Tudo isso dignifica e realiza subjetivamente quem o pratica. Essas práticas devem ser motivadas em todos os meios da sociedade, na família, Igreja, escola, MCS.

c) Conversão ecológica. Para os cristãos o Evangelho pode ser fonte de uma espiritualidade ecológica que muda a forma de pensar, sentir e viver. Os cristãos têm uma tradição rica a ser recuperada em favor de uma espiritualidade ecológica, mas têm que vencer os obstáculos do realismo pragmático, que tomou conta da vida, e da passividade que os impede de mudar hábitos. Para isso, o encontro com Jesus é a fonte principal de conversão. E não podemos nos esquecer de São Francisco de Assis como aquele que encarnou a conversão ecológica tratando a todos de irmãos e sendo incapaz de fazer o mal, sequer à menor das criaturas.

d) Alegria e Paz. A conversão ecológica implica em ser feliz e alegre e viver em paz com o mínimo necessário e não o máximo permitido. Alegrar-se com o pouco que se tem e não com o muito que se poderia ter e que causa angústia. Este é um segredo da espiritualidade cristã. A sobriedade é libertadora. 
Quem tudo quer, não encontra porto seguro para a alegria com o que tem, e vive a angústia do insatisfeito. Por que seguir os desejos, se esses são infinitos? Quem vive do alimentar esses desejos, vive infeliz e causa estragos na natureza. É preciso recuperar o ato de rezar, agradecer e contemplar, para mudar a forma de pensar, sentir e viver que, hoje, estão ancorados na posse e no consumo.

e) Amor cívico e político. Chegou a hora de reconhecer que o individualismo e a moral do egoísmo são desastrosos e que a honestidade, a bondade para com todo ser vivo, sobretudo, para com o próximo humano, é o que pode nos salvar. O egoísmo é destrutivo, enquanto o amor e o altruísmo, o respeito pelo bem comum é regenerativo. $\mathrm{O}$ amor, capaz de pequenos e grandes gestos, é também civil e político, "manifestando-se em todas as ações que procuram construir um mundo melhor" (n. 231). $\mathrm{O}$ amor à sociedade e o compromisso com o bem comum são a mais alta forma de caridade. Por isso, quem tem vocação para o mundo político propriamente dito, leve para dentro da política os valores cristãos, mas quem não tem vocação política profissional, saiba que toda ação em prol do bem comum é um ato político.

f) Os sinais sacramentais, a Trindade e Maria. Por fim, urge recuperar a dimensão sacramental do mundo criado. Tudo é obra de Deus e, se é obra de Deus, em cada ser Ele está. Será preciso um esforço para superar o dualismo que separa Deus e mundo e que não enxerga que Deus está na formiga, na árvore, na montanha, no ser vivo, em cada um dos animais, e que a ofensa, o sofrimento e a morte de cada um dos seres é sofrimento e morte do divino. Pensar o mundo como sinal sacramental de Deus é o que o cristão pode oferecer para uma conversão ecológica de inspiração cristã. Além disso, os sacramentos que a Igreja oferece são modos eficazes de perceber como a natureza é assumida e elevada integralmente por Deus. Um Deus trinitário e relacional é modelo de nosso ser e modelo da relação com os outros, com a natureza e com o próprio Deus. Maria, na visão cristã, é a rainha de toda a criação. A sua glorificação, juntamente com o Cristo Ressuscitado, antecipa a glorificação de toda a criação, inclusive a nossa. De Maria, o Papa recorda o seu engajamento compassivo, mas ativo, 
modelo de atitude para todo cristão: "Assim como chorou, com o coração trespassado, a morte de Jesus, assim também agora Se compadece do sofrimento dos pobres crucificados e das criaturas deste mundo exterminadas pelo poder humano" (n.241).

\section{Apreciação pessoal}

O acima exposto pretendeu ser um guia de leitura da encíclica, destacando o que apareceu com mais incidência, evidência, insistência e até a novidade no trato da questão ecológica. Como vimos, não são poucas as intuições do Papa e o alcance dessas intuições para um possível debate em torno do tema. $O$ exposto não se ateve a nenhum comentário ou interpretação, apenas pretendeu reconstruir, de forma breve, os argumentos principais do texto.

Atrevo-me agora, finalmente, ao risco de uma também breve interpretação do que a encíclica representa para a Igreja, para a sociedade e para a nova percepção ecológica. A meu juízo cinco são as possíveis chaves de leitura interpretativas que merecem atenção.

1. Não é uma encíclica verde. É uma encíclica de ecologia integral ou orgânica. A ideia corrente é que quando se fala de ecologia estamos falando de preservação da natureza, e preservação da natureza comumente aparece como sinônimo de preservação das florestas e das águas. A encíclica não é um chamamento à preservação das florestas e das águas. Nem é um chamado à preservação da natureza, se entendermos a natureza como o mundo dos minerais, dos vegetais e, no máximo, dos animais. A encíclica é tudo isso, mas é muito mais. A encíclica é uma reflexão sobre ecologia integral, incluindo ai o verde, as águas, os animais, os humanos, sobretudo os mais vulneráveis e ameaçados por causa de uma antropologia desordenada, sob um paradigma desastroso que é o de produção, distribuição e consumo capitalista, que a encíclica o Papa identifica como paradigma tecnoeconômico. A crise é socioambiental e não somente ambiental. E daria para dizer que a crise é socioambiental, econômica, política e ética, para verdadeiramente pensar a crise de forma integral. A partir da Laudato si, não somos mais autorizados a pensar fragmentariamente, mas convocados a pensar complexa e 
integralmente, localizando problemas conexos com causas conexas e relacionadas. O Papa nos dá uma lição de como se pode pensar a partir do novo paradigma, o paradigma da complexidade e da integralidade, que articula política, economia, sociedade, meio ambiente e pessoalidade.

2. Não é uma encíclica ideológica. É uma encíclica entre teologia, ética e ciências. Uma possível avaliação da encíclica seria de que ela é um texto de cunho ideológico, anti-capitalista e, portanto, inclinada ao ecossocialismo. Nada mais falso. Primeiro, porque a encíclica não é uma negação do capitalismo e nunca utiliza o termo capitalismo. Ela é uma insistente e dura crítica ao paradigma da divinização do mercado na sua lógica de lucro infinito, na exploração infinita e no desequilíbrio insustentável, tanto da natureza quanto dos seres vivos, sobretudo do humano mais vulnerável. Segundo, porque não há uma tomada de posição a favor de um possível socialismo ou outro modelo econômico alternativo ao capitalismo, supostamente, o socialismo. Terceiro e mais importante, a encíclica não se inspira em filósofos, economistas ou ideólogos. O que inspira a encíclica é a Bíblia, promovendo ou assumindo uma guinada na teologia da criação e numa acertada imagem trinitária de Deus, das tradições espirituais e teológicas, sobretudo, a de São Francisco de Assis. O corte é, portanto, teológico e ético, em diálogo com as ciências e com o magistério episcopal da Igreja. O que importa é perceber que o Papa ajuda os cristãos a se livrarem de uma hermenêutica bíblica que dava razão aos ambientalistas que nos acusavam de sermos o fundamento último de uma postura antropocêntrica diante da natureza. A hermenêutica do Papa, do evangelho da criação, tira o foco do "dominai e submetei" (Gn 1,28) para o "cultivar e guardar" (Gn 2,15). A partir dessa interpretação a eco-nomia (cultivar) não pode ser dissociada da eco-logia (guardar).

3. Não é uma encíclica para fechar o debate, mas para estimulálo. A encíclica não é um dogma de fé. Não é uma doutrina para se crer. Não é um conjunto de proposições para se gravar e para repetir. Não. A encíclica é uma provocação ao debate e uma provocação para sair do estado de crise ecológica em que nos encontramos. É um estímulo ao diálogo. Ela é fruto da colegialidade dos bispos em suas conferências, agora elevadas 
ao status de magistério papal, nesta encíclica. Ela é também fruto do acolhimento de vozes da ciência e da filosofia que ajudam a compreender a crise ecológica e suas causas, e as possíveis dimensões da ação para sair da crise. Mas ela é, sobretudo, uma provocação à ação e à conversão, não só dos fiéis católicos, mas de todos os habitantes da terra. O Papa diz abertamente que não cabe à Igreja apresentar soluções, mas estimular o debate para que a humanidade, nos seus mais diversos organismos e instâncias de poder, procure as soluções.

4. Não é uma encíclica datada. É uma encíclica para o futuro. A encíclica veio para ficar, pois os problemas e suas causas serão de agora em diante percebidas com nitidez tanto para o magistério da Igreja quanto para os teólogos, que terão de incluir no debate da fé o respeito à natureza e a tudo o que nela habita, por uma questão de ordem teológica, relacionada diretamente com Deus. É Deus que deseja um novo céu e uma nova terra. É Deus que inspira o Papa a prestar atenção aos sinais dos tempos e a ler os sinais dos tempos, de crise ecológica, como lugar da fala de Deus. Neste sentido, a encíclica não é para este ano. A encíclica não cairá no esquecimento por superação do tema nela abordado. E não poderá simplesmente ser colocada no âmbito do ensino social da Igreja. Ela é teologia por excelência. De tal forma que, de agora em diante, não mais se poderá falar de Deus sem falar de ecologia integral. O desafio da Igreja e dos organismos da sociedade civil, sobretudo dos movimentos ecológicos e sociais, é não deixar a encíclica cair no esquecimento.

5. Não é uma encíclica para os amantes da ecologia. É uma encíclica de provocação para todos. Os que melhor receberam a encíclica foram os ecologistas, em seus vários movimentos, e os teólogos da libertação, sobretudo os da ecoteologia. Mas a encíclica não é para os ecologistas e amantes da natureza ou para os teólogos da libertação. A encíclica é para todos, homens de fé ou não, indivíduos e empresas, organizações da sociedade civil e do Estado, base da Igreja e magistério da Igreja. A casa é comum e a causa também é comum. A solução depende de todos. A convocação à conversão ecológica é universal. A encíclica não é só um despertar da consciência ecológica. Isso outros autores, e mesmo organismos internacionais, já 
tinham feito. A encíclica é uma provocação. Provoca para a ação e não somente desperta a consciência para o problema, localizando as causas do mesmo. Por isso desde agora acabou a inocência. $\mathrm{O}$ que fizermos ou não fizermos não pode ser isento de responsabilidade. Já não dá mais para dizer: eu não sabia!

Recebido em: 21/06/2016

Aprovado em: 13/09/2016 